\title{
The effect of coral polyp sizes and coral exudates on picoeukaryote dynamics in a controlled environment
}

\author{
YING-PIN WANG ${ }^{1}$, KWEE SIONG TEW ${ }^{1,2}$, JIMMY KUO ${ }^{2,3}$, FUNG-CHI KO ${ }^{1,2}$ \\ and PEI-JIE MENG ${ }^{1,2}$ \\ ${ }^{1}$ Institute of Marine Biodiversity and Evolutionary Biology, National Dong Hwa University, 2 Houwan Road, 94450 \\ Checheng, Pingtung, Taiwan. \\ ${ }^{2}$ National Museum of Marine Biology and Aquarium, 2 Houwan Road, 94450 Checheng, Pingtung, Taiwan. \\ E-mail: tewks@nmmba.gov.tw \\ ${ }^{3}$ Institute of Marine Biotechnology, National Dong Hwa University, 2 Houwan Road, 94450 Checheng, Pingtung, Taiwan.
}

\begin{abstract}
SUMMARY: We examined the ability of scleractinian corals with different polyp sizes to remove picoeukaryotes by predation and the effect of coral exudates on picoeukaryote growth. Experiments were conducted by adding picoeukaryotes to Stylophora pistillata (SP) and Montipora stellata (MS). Within six hours the picoeukaryote concentration in the SP and MS tanks was significantly lower than the control without corals. SP showed higher overall activity than MS, and the particle removal activity of MS decreased in light conditions. Picoeukaryotes exposed to SP exudates grew significantly denser than those exposed to MS exudates or those in water without coral exudates. Dissolved organic carbon concentrations in the SP tanks were also significantly higher. We concluded that the picoeukaryote removal rates were higher in S. pistillata than in M. stellata, and coral exudates can reciprocally enhance picoeukaryote growth.
\end{abstract}

Keywords: scleractinian corals, Stylophora pistillata, Montipora stellata, picoeukaryotes, grazing, coral exudates.

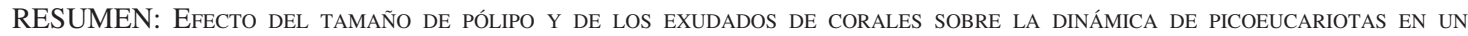
AMBIENTE CONTROLADO. - Hemos estudiado la capacidad de corales escleractinios con diferentes tamaños de pólipo de depredar picoplancton eucariótico, y también el efecto de los exudados de los corales sobre el crecimiento de picoplancton eucariótico. Los experimentos se realizaron añadiendo picoplancton eucariótico a Stylophora pistillata (SP) y Montipora stellata (MS). Después de 6 horas, las concentraciones de picoplancton eucariótico en los tanques de SP y MS fueron significativamente reducidas, en comparación con las del tanque control sin coral. SP mostró en general una actividad depredadora algo más grande que MS, y éste redujo su actividad en condiciones de luz. Los picoeucariotas expuestos a exudados de SP llegaron a concentraciones más altas que cuando fueron expuestos a exudados de MS o a agua sin corales. La concentración de carbono orgánico disuelto en los tanques de SP también fué significativamente más alta. Se concluye que las tasas de depredación sobre los picoeukaryotes fueron más altas con S. pistillata que con M. stellata, y que los exudados del coral pueden recíprocamente mejorar el crecimiento de picoplancton eucariótico.

Palabras clave: corales escleractínidos, Stylophora pistillata, Montipora stellata, picoeucariotas, depredación, exudados de corales.

\section{INTRODUCTION}

Picoplankton (0.2 to $2.0 \mu \mathrm{m})$ and nanoplakton (2.0 to $20 \mu \mathrm{m})$ are ubiquitous in the ocean ( $\mathrm{Li}$ et al. 1983, Tremblay and Legendre 1994). Among them, autotrophic picoplankton can contribute more than $70 \%$ to the primary production (Marañón et al. 2001), while pico- and nanoplankton contribute 50 to $100 \%$ to the total chlorophyll $a$ concentration in coral reef areas (Ferrier-Pagès and Gattuso 1998). Houlbrèque et al. (2006) showed that autotrophic plankton $<10 \mu \mathrm{m}$ (Synechococcus sp., Prochlorococcus sp., picoeukaryotes and nanoplankton) contributed $74 \%$ of the total chlorophyll $a$ and $47 \%$ of the total carbon in the Mayotte Island coral reef ecosystem, while the benthic organisms in the area consumed $30-45 \%$ of the total picoplank- 
tonic chlorophyll $a$. Thus, pico- and nanoplakton are an important link between pelagic and benthic ecosystems (Picciano and Ferrier-pagès 2007, Houlbrèque and Ferrier-Pagès 2009, Naumann et al. 2009), transferring nutrients such as nitrogen and phosphorus to benthic organisms.

Marine picoplankton consists of heterotrophic bacteria, pico-cyanobacteria (Prochlorococcus sp. and Synechococcus sp.) and picoeukaryotes. In one coral reef area, heterotrophic bacteria were the most abundant picoplankton $\left(10^{5} \sim 10^{6}\right.$ cells $\left.\mathrm{ml}^{-1}\right)$, followed by Synechococcus sp. and Prochlorococcus sp. $\left(10^{4} \sim 10^{5}\right.$ cells $\left.\mathrm{ml}^{-1}\right)$, and then picoeukaryotes $\left(10^{3}\right.$ cells $\left.\mathrm{ml}^{-1}\right)$ (Chang-Chou 2010). However, in terms of nutritional content, picoeukaryotes have the highest carbon and nitrogen content (Verity et al. 1992, Gundersen et al. 2002, Heldal et al. 2003).

Pico- and nanoplankton are consumed by benthic communities such as sponges (Gast et al. 1998, Richter et al. 2001), bivalves (Klumpp et al. 1992, Kach and Ward 2008), tunicates (Ribes et al. 2005), soft corals (Fabricius et al. 1995) and other animals. Some scleractinian corals have also been shown to feed on picoplankton, both in situ and in control tanks (Ribes et al. 2003, Houlbrèque et al. 2004a, Picciano and Ferrier-Pagès 2007), and acquire nutrients such as phosphorus, nitrogen and other essential elements from these microorganisms (Sorokin 1973, Ayukai 1995, Picciano and Ferrier-Pagès 2007, Naumann et al. 2009). Although energetically zooplankton contributes more than the other prey items (e.g. picoplankton, ciliates and dinoflagellates) to the corals (Ribes et al. 1999), the importance of picoplankton in the coral reef ecosystem should not be overlooked.

Porter (1976) pointed out that corals with larger polyps and a lower surface to volume ratio ( $\mathrm{S} / \mathrm{V}$ ratio) tended to remove particles from the water column more efficiently than those with smaller polyps and a higher $\mathrm{S} / \mathrm{V}$ ratio as a trade off between a high surface area for photosynthesis and an enhanced ability to capture zooplankton. However, the prey capture rate has also been found to be higher in corals with small polyps than in corals with large polyps (Sebens 1987; Sebens et al. 1996). Whether the success in capturing picoplankton differs between coral polyp sizes remains unclear.

The role played by organic matter released by corals in stimulating picoplankton growth needs to be studied further. Particulate organic matter (POM) and dissolved organic matter (DOM) contribute to high productivity in coral reef areas (Moriarty 1979), and coral mucus is an important source of POM and DOM (Crossland 1987) in the ecosystem. The bacterial productivity was ten times higher after water had flowed through a patch of coral reef (Moriarty et al. 1985), indicating the importance of mucus for the growth of microorganisms in the reef ecosystem (Brown and Bythell 2005). Ferrier-Pagès et al. (2000) showed that small amounts of coral mucus are enough to enhance microbial growth. However, whether the exudates could stimulate photosynthetic picoeukaryote growth in a short period of time is unknown.

Despite the fact that scleractinian corals can feed on a large range of food particles (Houlbrèque et al. 2004b; Picciano and Ferrier-Pagès, 2007), it is not clear whether polyp sizes affect the capture of small particles such as picoplankton. By conducting experiments in the laboratory, we aimed to (1) examine the removal rates of picoeukaryotes by corals with different polyp sizes, and (2) compare the growth of picoeukaryotes given different coral exudates.

\section{MATERIALS AND METHODS}

Two scleractinian coral species, Stylophora pistillata (SP) and Montipora stellata (MS), with large and small polyps respectively, were chosen for the experiments. The picoeukaryote (mean size \pm se: $1.95 \pm 0.12$ $\mu \mathrm{m}, 50$ living cells measured by optical microscopy with a calibrated micrometer) used in the experiments was a new phototrophic species (Nannochloropsis sp.) isolated from an adjacent lagoon and cultured axenically in $\mathrm{f} / 2$ medium at $25^{\circ} \mathrm{C}$ with a $12: 12 \mathrm{~h}$ light-dark cycle. Picoeukaryotes were chosen over cyanobacteria (i.e. Synechococcus or Prochlorococcus) because their ecological roles in these feeding and growth relationships with scleractinian corals have been studied less.

Experiments were conducted using 10-1 glass tanks filled with filtered natural sea water $(0.22 \mu \mathrm{m}$, Millipore), and illuminated by fluorescent light bulbs under a 12:12 hr light-dark cycle, with an intensity of about $100 \mu$ mol photon $\mathrm{m}^{-2} \mathrm{~s}^{-1}$ just below the surface. The water was kept moving in the tanks using a submerged pump at an average speed of $8 \mathrm{~cm} \mathrm{~s}^{-1}$ in a closed circuit. A room temperature of $25^{\circ} \mathrm{C}$ was used during the entire experimental period.

Experiment 1 (Exp. 1) was designed to examine the efficiency of corals of different polyp sizes in removing picoeukaryotes. Tanks with Stylophora pistillata (colony diameter: $9.43 \pm 0.15 \mathrm{~cm}, \mathrm{n}=3$; polyp diameter: $1.15 \pm 0.01 \mathrm{~mm}$, mean $\pm \mathrm{se}, \mathrm{n}=20)$, Montipora stellata (colony diameter: $11.03 \pm 0.37 \mathrm{~cm}, \mathrm{n}=3$, polyp diameter: $0.73 \pm 0.01 \mathrm{~mm}, \mathrm{n}=20$, mean $\pm \mathrm{se}$, ) and a control (empty tank) were set up in triplicate. Each coral was hung in the middle of the tank with a nylon thread and allowed to assimilate for two days before the experiment. At the start of the experiment, cultured picoeukaryotes were added to each tank to a final concentration of $10^{5}$ cell $\mathrm{ml}^{-1}$ (two orders of magnitude higher than natural conditions). This was to facilitate the enumeration of the algal concentration using flow cytometry, with a minimum effect on coral physiology. Two experimental runs were conducted, each lasting for $6 \mathrm{~h}$, one to simulate conditions during the day (with light) and one to simulate conditions during the night (in darkness). At the end of the experiment, the surface area of each coral was measured according to Stimson and Kinzie (1991). 
Water samples $(2 \mathrm{ml}, \mathrm{n}=3)$ were taken from each tank every 30 min for $6 \mathrm{~h}$, fixed with glutaraldehyde in the dark, preserved in liquid nitrogen and then stored at $-80^{\circ} \mathrm{C}$ (Vaulot et al. 1989, Blanchot and Rodier 1996). Picoeukaryote counts were made with a flow cytometer (Quanta, Beckman-Coulter, with a laser emitting at $488 \mathrm{~nm}$ ) as detected by high red fluorescence and no orange fluorescence.

Specific removal rates were calculated taking into account the growth of picoeukaryotes during the incubation (Ribes et al. 1998). The specific apparent picoeukaryote grazing rate $\left(k, \mathrm{~h}^{-1}\right)$ was calculated by adjusting a negative exponential curve to the concentration data measured during the experimental period (13 data points from each tank, from 0.5 to $6.0 \mathrm{~h}$, time 0 included). The specific picoeukaryote growth rate $\left(\mu, \mathrm{h}^{-1}\right)$ was obtained by applying the same methodology to the control tanks. Finally, the specific grazing rate $\left(\mathrm{g}, \mathrm{h}^{-1}\right)$ was calculated as $\mathrm{g}=\mu$ - $\mathrm{k}$, and was carried out with and without normalizing to the surface area of the polyps. The removal rates $I$ (picoeukaryote removed colony ${ }^{-1} \mathrm{~h}^{-1}$ ) were calculated as:

$$
I=\left[\left(C_{0}-C_{t}\right) * v\right] / t
$$

where $C$ is the concentration of picoeukaryotes $v$ is the volume of the incubation medium ( $\mathrm{ml})$ and $t$ is incubation time (h) (Ferrier-Pages et al. 1998).

Experiment 2 (Exp. 2) examined the effect of coral exudates on the growth of the picoeukaryotes. Tanks with Stylophora pistillata (average diameter: $9.20 \pm 0.35 \mathrm{~cm}$, mean $\pm \mathrm{se}, \mathrm{n}=3$ ), Montipora stellata $(9.63 \pm 0.26 \mathrm{~cm}, \mathrm{n}=3)$ and a control (empty tank) were set up in triplicate. The corals were left assimilating for two days, and then removed from the tanks. The water in the tanks was filtered through $0.22 \mu \mathrm{m}$ to remove all organisms. Water samples from each tank were taken to measure the dissolved organic carbon (DOC) concentration (Aurora Model 1030W, O.I. Analytical, Texas). Picoeukaryotes were then added to the tanks to a final concentration of $10^{3}$ cell ml-1, and the tanks were maintained as previously mentioned. Water samples $(1 \mathrm{ml}, \mathrm{n}=3)$ were taken daily for $13 \mathrm{~d}$ at 0900 from each tank, fixed with glutaraldehyde, preserved in liquid nitrogen and then stored at $-80^{\circ} \mathrm{C}$ for later flow cytometry enumeration (Vaulot et al. 1989, Blanchot and Rodier 1996).

The results were statistically analyzed with ANOVA. The data from two of the tanks, one from $\mathrm{SP}_{\text {night }}$ and one from $\mathrm{MS}_{\text {night }}$, were removed because they were inconsistent with the other replicates. Significant differences were further analyzed with a post-hoc Tukey's test $(\alpha=0.05)$ to determine which categories differed. Before the analyses, concentration data were $\log$ transformed to meet the assumption of normality and homogeneity of variance. Statistical analyses were computed with the software package SigmaStat 2.03 (SPSS 1997).
TABLE 1. - Initial and final concentrations of picoeukaryotes (means $\pm \mathrm{se}$ ) in the Montipora stellata (MS) and Stylophora pistillata (SP) tanks over $6 \mathrm{~h}\left(10^{3}\right.$ cell $\left.\mathrm{ml}^{-1}\right)$.

\begin{tabular}{lcccc}
\hline & \multicolumn{2}{c}{ MS } & \multicolumn{2}{c}{ SP } \\
& Initial & Final & Initial & Final \\
\hline Day & $259.4 \pm 4.5$ & $254.3 \pm 4.0$ & $258.4 \pm 1.9$ & $251.7 \pm 1.3$ \\
Night & $257.6 \pm 5.3$ & $248.0 \pm 0.5$ & $257.3 \pm 3.8$ & $244.9 \pm 1.9$ \\
Surface area / & $235.4 \pm 5.1$ & & $132.2 \pm 10.6$ \\
volume $\left(\mathrm{cm}^{2} / 4 \mathrm{~L}\right)$ & & & \\
\hline
\end{tabular}

\section{RESULTS}

Comparison of the initial and final picoeukaryote concentration in the different treatments of Exp. 1 over $6 \mathrm{~h}$ (Table 1) revealed a generalized trend of decreasing concentration in the coral-containing tanks, both in light and dark conditions. Specific picoeukaryote growth rates were negative in the coral-treated tanks, which means that cell concentrations decreased during the incubation while they remained stable or were just slightly negative in the control tanks (Fig. 1). Overall removal was greater in the SP tanks than in the MS tanks in light conditions and the opposite was true in the dark, as the removal increased greatly for MS from light to dark conditions. The removal rates of MS and SP in the light, normalized to the area of a colony, were $59 \pm 23 \times 10^{3}$ cells cm-2 $\mathrm{h}^{-1}$ and $87 \pm 30 \times 10^{3}$ cells $\mathrm{cm}^{-2} \mathrm{~h}^{-1}$ respectively, while the removal rates of MS and SP in the dark were $227 \pm 43 \times 10^{3}$

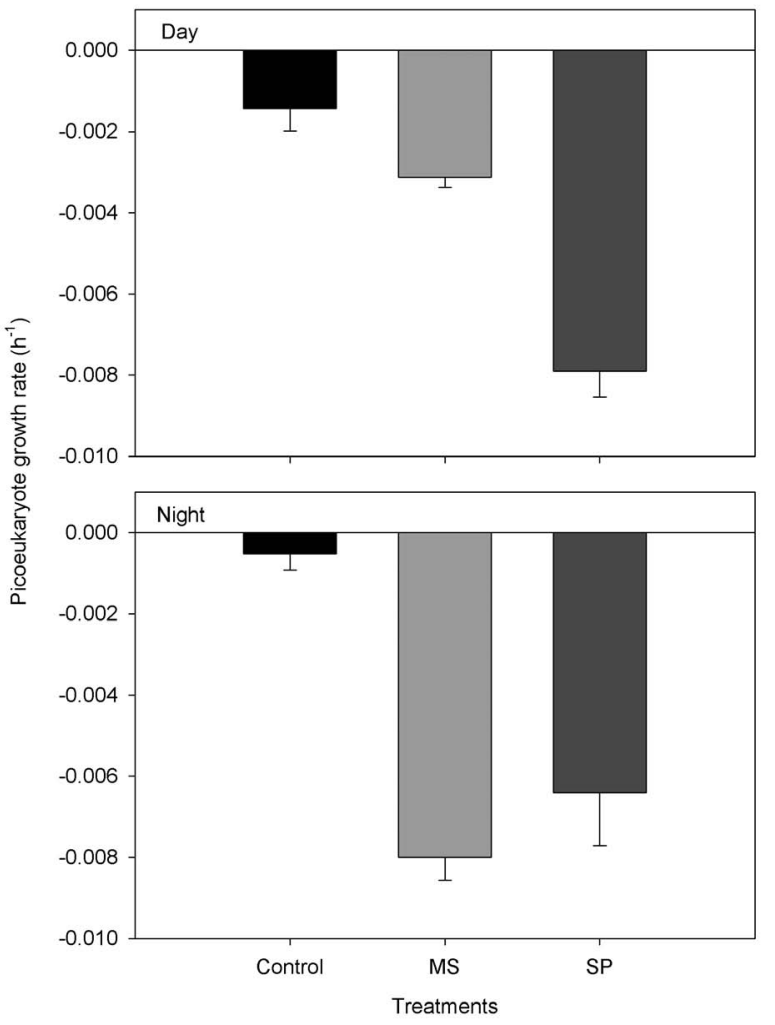

FIG. 1. - Picoeukaryote specific rate of change $\left(\mathrm{h}^{-1}\right.$, means \pm se $)$ in the Stylophora pistillata (SP), Montipora stellata (MS) and control tanks. 


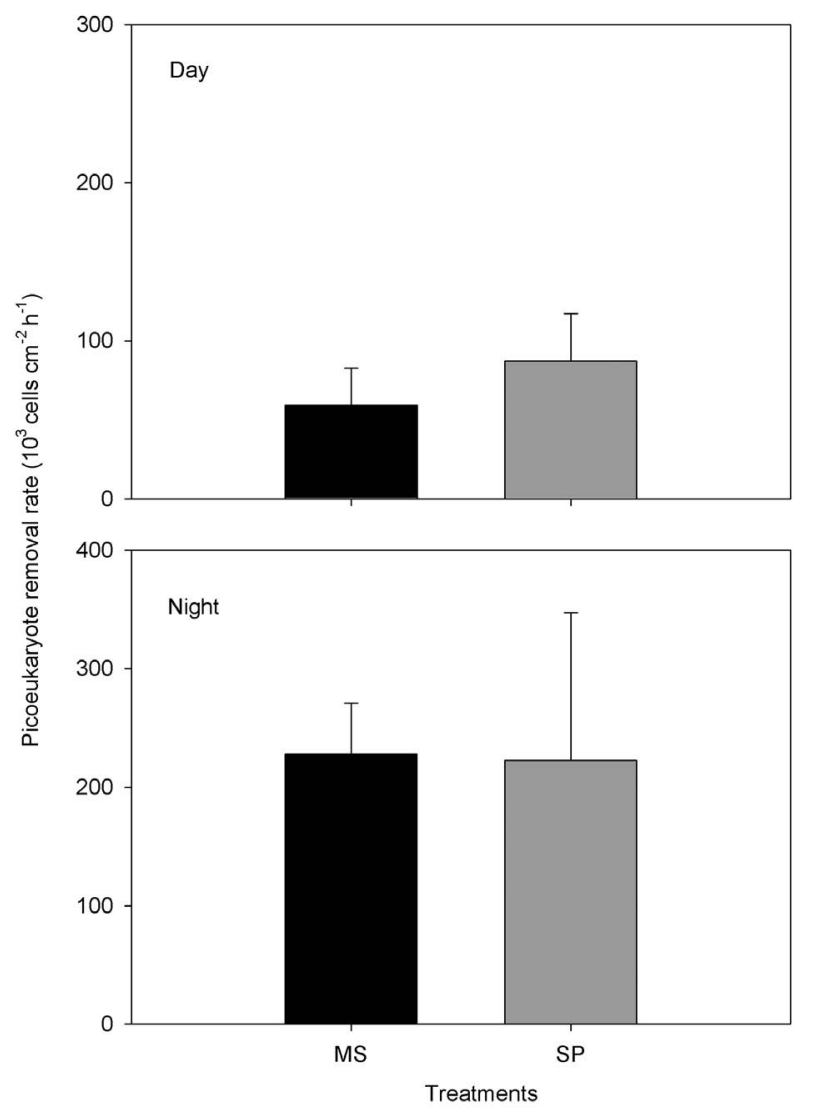

FIG. 2. - Picoeukaryotes removal rates (means \pm se, $n=3$ ) by Stylophora pistillata (SP) and Montipora stellata (MS) over $6 \mathrm{~h}$.

cells $\mathrm{cm}^{-2} \mathrm{~h}^{-1}$ and $222 \pm 124 \times 10^{3}$ cells $\mathrm{cm}^{-2} \mathrm{~h}^{-1}$ respectively (Fig. 2). The specific grazing rates on picoeukaryotes (Fig. 3) that had been normalized for polyp area were higher for SP under both light and dark conditions, even though the grazing rates of MS increased significantly in the dark with respect to the light. The two-way ANOVA (Table 2) revealed that the normalized area was significantly higher for SP than for MS while no overall difference was found for the corals exposed to light or dark conditions. However, a significant interaction between species and light/dark conditions revealed that MS shows significantly reduced grazing rates in the light while this was not the case for SP (post-hoc Tukey $\mathrm{HSD}, \mathrm{MS}_{\text {light }}<\mathrm{MS}_{\text {dark }} \approx \mathrm{SP}_{\text {dark }} \approx \mathrm{SP}_{\text {light }}$ ).

When the growth of picoeukaryotes was examined with different coral exudates (Fig. 4), we found that the total abundance of picoeukaryotes in the SP tanks had increased significantly after four days, and after eight

TABLE 2. - Two-way ANOVA for polyp-area normalized specific grazing rates on picoeukaryotes. Treatments are between species and day/night.

\begin{tabular}{lcrrrc}
\hline Source of Variation & DF & \multicolumn{1}{c}{ SS } & \multicolumn{1}{c}{ MS } & \multicolumn{1}{c}{$F$} & $p$ \\
\hline Species & 1 & 1569.996 & 1569.996 & 23.54 & 0.003 \\
Day/night & 1 & 206.489 & 206.489 & 3.096 & 0.129 \\
Interaction & 1 & 608.629 & 608.629 & 9.126 & 0.023 \\
Residual & 6 & 400.169 & 66.695 & & \\
\hline
\end{tabular}

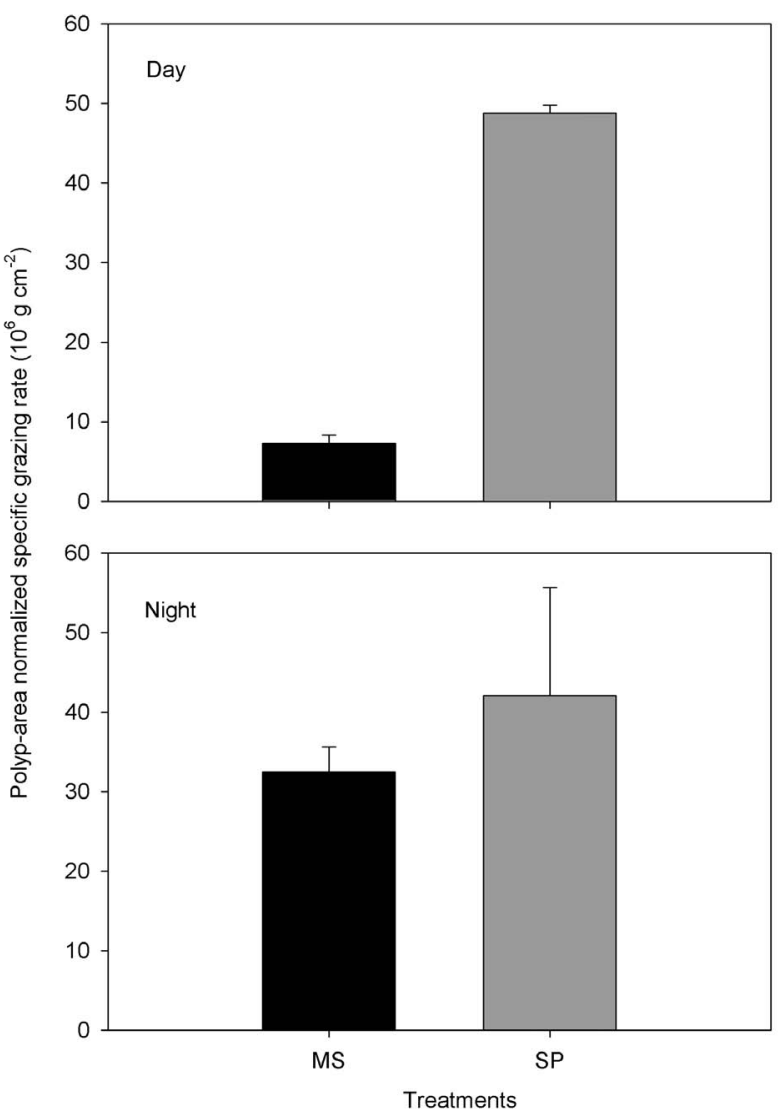

FIG. 3. - Polyp-area normalized specific grazing rate on picoeukaryotes (means \pm se) for Stylophora pistillata (SP) and Montipora stellata (MS).

days it had increased to almost ten times the original concentration, and was still at about eight times this original concentration by the end of the experiment. An ANOVA with data from time $13 \mathrm{~d}$ showed significantly higher picoeukaryote densities in SP than in MS and the control tanks $(\mathrm{F}=28.649$, $\mathrm{df}=38, \mathrm{~N}=39, \mathrm{p}<0.001)$. Picoeukaryotes increased by $163 \%$ (MS) and $42 \%$ (control) with respect to the initial conditions.

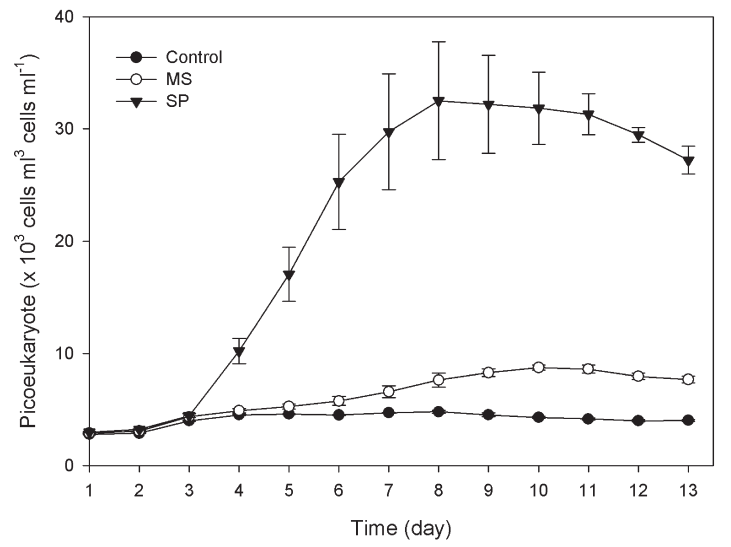

FIG. 4. - Concentration of picoeukaryotes (means \pm se, $n=3$ ) cultured in the exudates of Stylophora pistillata (SP), Montipora stellata (MS) and control tanks over $13 \mathrm{~d}$. 


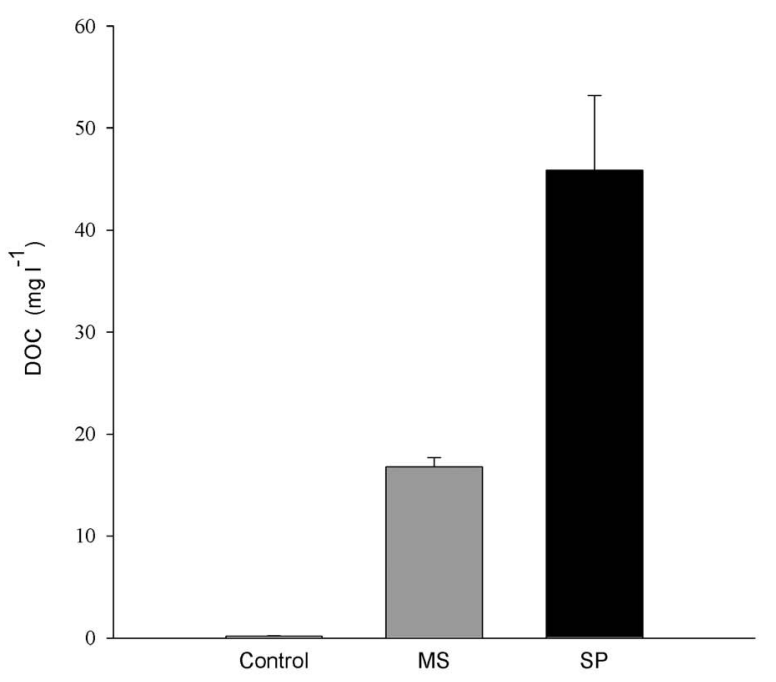

FIG. 5. - Dissolved organic carbon concentration (means \pm se, $n=3$ ) in the Stylophora pistillata (SP), Montipora stellata (MS) and control tanks. All three categories were significantly different from each other $(\mathrm{p}<0.001)$.

DOC concentrations (Fig. 5) were significantly different $(\mathrm{F}=756.244, \mathrm{df}=8, \mathrm{~N}=9, \mathrm{p}<0.001)$ after two days in the incubations, with the highest average concentration in the SP tanks $\left(45.87 \pm 7.29 \mathrm{mg} \mathrm{l}^{-1}\right)$ followed by the MS tanks $\left(16.78 \pm 0.90 \mathrm{mg} \mathrm{l}^{-1}\right)$. Both were significantly higher than the control $\left(0.20 \pm 0.01 \mathrm{mg} \mathrm{l}^{-1}\right)$.

\section{DISCUSSION}

\section{Grazing of corals on picoeukaryotes}

Studies on the heterotrophic aspect of corals focus primarily on the predation of large organisms, such as zooplankton, because larger prey are easier to identify and quantify when coral gut contents are examined, and their energy input is also comparatively large (Coma et al.1994, Ferrier-Pagès et al. 2003, Houlbrèque et al. 2004b). However, studies on the predation of picoplankton by symbiotic and aposymbiotic corals revealed that picoplankton may be the most important source of nitrogen, phosphorus and other essential elements (Houlbrèque et al. 2004a, Picciano and Ferrierpagès 2007). Among the picoplankton groups, picoeukaryotes have the highest carbon and nitrogen contents (Verity et al. 1992, Gundersen et al. 2002, Heldal et al. 2003), but are the least studied in terms of this transfer process.

This study shows that both coral species, S. pistillata with large polyps and M. stellata with small polyps, can remove picoeukaryotes from the water. The polyp diameters of $S$. pistillata and $M$. stellata in this study were $1.0 \sim 1.2 \mathrm{~mm}$ and $0.7 \sim 0.8 \mathrm{~mm}$ respectively. The polyp-area normalized specific grazing rates showed that $S$. pistillata was more efficient in removing picoeukaryote particles than $M$. stellata. This is in accordance with Porter (1976) who pointed out that corals with larger polyps and a lower surface to volume ratio ( $\mathrm{S} / \mathrm{V}$ ratio) tended to remove particles from the water column more efficiently than those with smaller polyps and a higher $\mathrm{S} / \mathrm{V}$ ratio. Other studies also found that corals with larger polyps tended to be more efficient in removing particles (Muscatine et al. 1989, Houlbrèque et al. 2004a) and obtain a higher amount of nitrogen and carbon from their prey (Houlbrèque $e t$ al. 2004a). S. pistillata is a branching coral with a low $\mathrm{S} / \mathrm{V}$ ratio and dense polyps, which allows it to capture particulate matter from the water column, whereas $M$. stellata forms plate-like colonies with a higher surface area available for photosynthesis and perhaps needs to rely less on capturing prey. Under the higher-thannormal density of picoeukaryotes in our experimental set-up, with no change in light penetration into the tank (data not shown), M. stellata still tended to undergo photosynthesis in our light treatment but it only removed a few picoeukaryotes. However, $S$. pistillata actively removed picoeukaryotes both with light and in the dark. This shows that the two species have different activity rhythms. We expected that both species would prey heavily on the picoeukaryotes, both with light and in the dark, when provided with higher-than-normal food particles, since we observed that all the specimens (including those that were not used in the experiments) extended their tentacles $24 \mathrm{~h}$ a day.

As well as using tentacles to actively capture particles, some corals also excrete mucus to entangle particulate food in the water column (Goldberg 2002, Houlbrèque et al. 2004a, Naumann et al. 2009). Goldberg (2002) found that the scleractinian coral Mycetophyllia reesi captured food particles by mucus entanglement and collected the mucus-embedded particulates through mesenterial filaments emerging from the oral opening. Naumann et al. (2009) reported high Synechochoccus enrichment in Acropora mucus, which indicates that coral mucus has efficient picoplankton trapping potential. A six day experiment (in exactly the same experimental setting) showed almost $100 \%$ clearance of picoeukaryotes by $S$. pistillata but not by $M$. stellata (Wang, 2009), suggesting that entanglement of particulate food might be more efficient in S. pistillata than in $M$. stellata.

Thus, differences in picoeukaryote removal between species seem to depend not only on polyp sizes but also on the overall species physiology during a diel cycle. Presumably, corals can acquire nutrients from both symbiotic algae and particles in the water under light conditions, whereas in dark conditions, obtaining nutrients from the environment is the only way to get enough resources for growth and metabolism (Ferrier-Pagès et al. 1998). Our results were basically in line with Ferrier-Pagès et al. (1998), who found that the removal of ciliates by $S$. pistillata decreased as light intensity increased. Another study conducted by Palardy et al. (2005) who relocated corals from 1 $\mathrm{m}$ deep to $6 \mathrm{~m}$ also found that the particle removal rate increased as the light intensity decreased. The 
long-term culturing of the specimens in an aquarium ( $>5 \mathrm{yr}$ ), or the presence of high concentrations of picoeukaryotes in the water, did not seem to affect coral grazing behavior.

\section{Picoeukaryote growth enhancement by coral exudates}

Coral exudates contain high concentrations of dissolved organic carbon (DOC) but low concentrations of inorganic nutrients (Ferrier-Pagès et al. 2000). In this study, incubation of corals for two days greatly increased the concentrations of DOC (and presumably also both organic and inorganic nutrients) in the water column, and picoeukaryotes increased in density by up to ten times when they were exposed to coral exudates. A $10 \mathrm{~h}$ study on the effects of coral exudates on pico- and nanoplankton revealed that the autotrophic biomass was 3-5 times higher at the end of incubation, and concluded that just a few coral exudates is enough to stimulate microbial growth (Ferrier-Pagès et al. 2000). Although our experimental designs do not consider advection and diffusion effects in the field, these results still imply that coral exudates could be an important source of nutrients, even for photosynthetic picoeukaryotes, in an oligotrophic coral reef ecosystem. This would compare to the excretion of zooplankton in the open ocean (Biggs 1977, Hernández-León et al. 2008). The chemical content of coral exudates has not yet been thoroughly examined and should clearly be the object of further studies.

\section{CONCLUSIONS}

A great diversity of filter-feeders, such as ascidians, sponges, bivalves, polychaetes and crustaceans, thrive in the oligotrophic water of coral reefs (Houlbrèque et al. 2006). This study reveals that corals remove picoeukaryotes and also greatly enhance the growth of picoeukaryotes by means of exudates. In both processes $S$. pistillata is more active than $M$. stellata, which may have important ecological consequences. Corals seem to be an important source of nutrients to the surrounding water, which has not always been considered in enough detail, and picoplankton is likely an important source of food for the filter-feeder community in reef regions. Both top-down and bottom-up processes affect the primary producers in our study, and the degree of influence varies depending on the coral species. Further studies are needed to verify the roles played by picoeukaryotes in coral reefs, and whether corals are a relevant nutrient contributor to the picoautotrophs in the coral reef ecosystem.

\section{ACKNOWLEDGEMENTS}

We thank Dr. Ye HC for assisting with the flow cytometry, and Moisés SJ for the Spanish translation.
We are grateful to Dr. F. Peters and Dr. J. Shea for their valuable comments and to two anonymous reviewers for their suggestions on the manuscript. This work was supported by intramural funding from the National Museum of Marine Biology and Aquarium to K.S. Tew.

\section{REFERENCES}

Ayukai T. 1995. Retention of phytoplankton and planktonic microbes on coral reef within the Great Barrier Reef, Australia. Coral Reefs 14: 141-147.

Biggs D.C. 1977. Respiration and ammonium excretion by open ocean gelatinous zooplankton. Limnol. Oceanogr. 22: 108-117.

Blanchot J., Rodier M. 1996. Picophytoplankton abundance and biomass in the eastern tropical Pacific Ocean during the 1992 El Niño year: results from flow cytometry. Deep-Sea Res. 6: 877-895.

Brown B.E., Bythell J.C. 2005. Perspectives on mucus secretion on coral reef. Mar. Ecol. Prog. Ser. 296: 291-309.

Chang-Chou Y.Y. 2010. The effects of upwelling on picoplankton, phytoplankton and nutrients in Nanwan Bay. Masters thesis. National Dong Hwa University, Taiwan.

Coma R., Gili J.M., Zabala M. and Riera T. 1994. Feeding and prey capture cycles in the aposymbiotic gorgonian Paramuricea clavata. Mar. Ecol. Prog. Ser. 115: 257-270.

Crossland C.J. 1987. In situ release of mucus and DOC-lipid from the coral Acropora variabilis and Stylophora pistillata. Coral reefs $6: 35-42$.

Fabricius K., Benayahu Y., Genin A. 1995. Herbivory in asymbiotic soft corals. Science 268: 90-92.

Ferrier-Pagès C., Gattuso J.P. 1998. Biomass, production and grazing rates of pico and nanoplankton in coral reef waters (Miyako Island, Japan). Microb. Ecol. 35: 48-57.

Ferrier-Pagès C., Allemand D., Gattuso J.P., Jaubert J., Rassoulzadegan R. 1998. Microheterotrophy in the zooxanthellate coral Stylophora pistillata: effects of light and ciliate density. Limnol. Oceanogr. 43: 1639-1648.

Ferrier-Pagès C., Leclercq N., Jaubert J., Pelegri S.P. 2000. Enhancement of pico- and nanoplankton growth by coral exudates. Aquat. Microb. Ecol. 21: 203-209.

Ferrier-Pagès C., Witting J., Tambuttè E., Sebens K.P. 2003. Effect of natural zooplankton feeding on the tissue and skeletal growth of the scleractinian coral Stylophora pistillata. Coral Reefs 22: 229-240.

Gast G.J., Wiegman S., Wieringa E., van Duyl F.C., Bak R.P.M. 1998. Bacteria in coral reef water types: removal of cells, stimulation of growth and mineralization. Mar. Ecol. Prog. Ser. 167: $37-45$.

Goldberg W.M. 2002. Feeding behavior, epidermal structure and mucus cytochemistry of the scleractinian Mycetophyllia reesi, a coral without tentacles. Tissue Cell 34: 246-261.

Gundersen K., Heldal M., Norland S., Purdie D.A., Knap A.H. 2002. Elemental C, N and P cell content of individual bacteria collected at the Bermuda Atlantic Time-series Study (BATS) site. Limnol. Oceanogr. 47: 1525-1530.

Heldal M., Scanlan D.J., Norland S., Thingstad F., Mann N.H. 2003. Elemental composition of single cells of various strains of marine Prochlorococcus and Synechococcus using X-ray microanalysis. Limnol. Oceanogr. 48: 1732-1743.

Hernández-León S., Fraga C., Ikeda T. 2008. A global estimation of mesozooplankton ammonium excretion in the open ocean. $J$. Plankton Res. 30: 577-585.

Houlbrèque F., Tambutté E., Richard C., Ferrier-Pagès C. 2004a. Importance of the micro-diet for scleractinian corals. Mar. Ecol. Prog. Ser. 282: 151-160.

Houlbrèque F., Tambutté E., Allemand D., Ferrier-Pagès C. 2004b. Interactions between zooplankton feeding, photosynthesis and skeletal growth in the scleractinian coral Stylophora pistillata. J. Exp. Mar. Biol. Ecol. 207: 1461-1469.

Houlbrèque F., Delesalle B., Blanchot J., Montel Y., Ferrier-Pagès C. 2006. Picoplankton removal by the coral reef community of La Prévoyante, Mayotte Island. Aquat. Microb. Ecol. 44: 59-70.

Houlbrèque F., Ferrier-Pagès C. 2009. Heterotrophy in tropical scleractinian corals. Biol. Rev. Camb. Philos. Soc. 84: 1-17. 
Kach D.J., Ward J.E. 2008. The role of marine aggregates in the ingestion of picoplankton-size particles by suspension-feeding mollusks. Mar. Biol. 153: 797-805.

Klumpp D.W., Bayne B.L., Hawkins A.J.S. 1992. Nutrition of the giant clam Tridacna gigas. 1. Contribution of filter feeding and photosynthates to respiration and growth. J. Exp. Mar. Biol. Ecol. 155: 105-122.

Li W.K.W, Subba Rao D.V., Harrison W.G., Smith J.C., Cullen J.J., Irwin B., Platt T. 1983. Autotrophic picoplankton in the tropical ocean. Science 219: 292-295.

Marañón E., Holligan P.M., Barciela R.M., Gonzalez N., Mourino B., Pazo M.J., Varela M. 2001. Patterns of phytoplankton size structure and productivity in contrasting open-ocean environments. Mar. Ecol. Prog. Ser. 216: 43-56.

Moriarty D.J.W. 1979. Biomass of suspended bacteria over coral reefs. Mar. Biol. 92: 457-464.

Moriarty D.J.W., Pollard P.C., Hunt W.G. 1985. Temporal and spatial variation in bacterial production in the water column over a coral reef. Mar. Biol. 85: 285-292.

Muscatine L., Porter J.W., Kaplan I.R. 1989. Resource partitioning by reef corals as determined from stable isotope composition. Mar. Biol. 100: 185-193.

Naumann M.S., Richter C., el-Zibdah M., Wild C. 2009. Coral mucus as an efficient trap for picoplanktonic cyanobacteria: implications for pelagic-benthic coupling in the reef ecosystem. Mar. Ecol. Prog. Ser. 385: 65-76.

Palardy J.E., Grottoli A.G., Matthews K.A. 2005. Effects of upwelling, depth, morphology and polyp size on feeding in three species of Panamanian corals. Mar. Ecol. Prog. Ser. 300: 79-89.

Picciano M., Ferrier-Pagès C. 2007. Ingestion of pico- and nanoplankton by the Mediterranean red coral Corallium rubrum. Mar. Biol. 150: 773-782.

Porter J.W. 1976. Autotrophy, heterotrophy, and resource partitioning in Caribbean reef-building corals. Am. Nat. 110: 731-742.

Ribes M., Coma R., Gili J.M. 1999. Heterogeneous feeding in benthic suspension feeders: the natural diet and grazing rate of the temperate gorgonian Paramuricea clavata (Cnidaria: Octocorallia) over a year cycle. Mar. Ecol. Prog. Ser. 183: 125-137.

Ribes M., Coma R., Atkinson M.J., Kinzie R.A. 2003. Particle removal by coral reef communities: picoplankton is a major source of nitrogen. Mar. Ecol. Prog. Ser. 257: 13-23.

Ribes M., Coma R., Atkinson M.J., Kinzie R.A. 2005. Sponges and ascidians control removal of particulate organic nitrogen from coral reef water. Limnol. Oceanogr. 50: 1480-1489.

Richter C., Wunsch M., Rasheed M., Kötter I., Badran M.I. 2001. Endoscopic exploration of Red Sea coral reefs reveals dense populations of cavity-dwelling sponges. Nature 413: 726-730.

Sebens, K.P. 1987. Coelenterata. In: F.J. Vernberg and T.J. Pandian (eds.), Animal energetics Vol. 1, pp. 55-120. Academic Press, New York.

Sebens K.P., Vandersall K.S., Savina L.A., Graham K.R. 1996. Zooplankton capture by two scleractinian corals, Madracis mirabilis and Montastraea cavernosa, in a field enclosure. Mar. Biol. 127: 303-317.

Sorokin Y.I. 1973. Trophical role of bacteria in the ecosystems of the coral reef. Nature 242: 415-417.

SPSS. 1997. SigmaStat statistical software. SPSS Marketing Department, Chicago, IL.

Stimson J., Kinzie R.A. 1991. The temporal pattern and rate of release of zooxanthellae from the reef coral Pocillopora damicornis (Linnaeus) under nitrogen-enrichment and control conditions. J. Exp. Mar. Biol. Ecol. 153: 63-74.

Tremblay J.E., Legendre L. 1994. A model for the size-fractioned biomass and production of marine phytoplankton. Limnol. Oceanogr. 39: 2004-2014.

Verity P.G., Robertson C.Y., Tronzo C.R., Andrews M.G., Nelson J.R., Sieracki M.E. 1992. Relationship between cell volume and the carbon and nitrogen content of marine photosynthetic nanoplankton. Limnol. Oceanogr. 37: 1434-1446.

Vaulot D., Courties C., Partensky F. 1989. A simple method to preserve oceanic phytoplankton for flow cytometric analyses. Cytometry 10: 629-635.

Wang Y.P. 2009. Interactions between picoeukaryote and scleractinian corals. Masters thesis. National Dong Hwa University, Taiwan.

Scient. ed.: F. Peters.

Received April 26, 2011. Accepted March 7, 2012.

Published online August 2, 2012. 